\title{
COMPARISON OF THE EFFECTS OF GROWTH REGULATORS ON IN VITRO REGENERATION OF RIDGE GOURD AND SPONGE GOURD THROUGH SHOOT
}

\author{
E Nahar, ME Haque, B Sikdar* \\ Department of Genetic Engineering and Biotechnology, University of Rajshahi, Rajshahi 6205, Bangladesh
}

\begin{abstract}
Context: Luffa cylindrica and Luffa acutangula are highly cross pollinated crops and propagated mainly by seeds. Genetic stability cannot be maintained easily by seed propagation. It can be maintain by developing special vegetative technique through tissue culture.

Objectives: To compare the effects of growth regulators between two species of Luffa using shoot tips for develop the rapid, simple and efficient in vitro regeneration protocol.

Materials and Methods: Shoot tips used were collected from in vivo grown plants. They were excised from plants and surface sterilized by $\mathrm{HgCl}_{2}$ treatment. The isolated tips were cultured on semisolid MS medium supplemented with different concentrations and combinations of different growth regulators.

Results: The highest result of direct shoot multiplication of ridge gourd was observed using $2 \mathrm{mg} / \mathrm{l} \mathrm{BAP}+0.2 \mathrm{mg} / \mathrm{l}$ $\mathrm{GA}$ and in case of sponge gourd it was $1.5 \mathrm{mg} / \mathrm{l} \mathrm{BAP}$. For callus induction significant result was found using $4 \mathrm{mg} / \mathrm{l}$ $\mathrm{BAP}+0.2 \mathrm{mg} / \mathrm{NAA}$ in ridge gourd and $3 \mathrm{mg} / \mathrm{BAP}+0.2 \mathrm{mg} / \mathrm{lNA}$ in sponge gourd. Indirect regeneration was performed by subculturing organogenic callus of sponge gourd on MS with $1.5 \mathrm{mg} / \mathrm{BAP}+0.2 \mathrm{mg} / \mathrm{GA}$ and the callus of ridged gourd on MS + $1.5 \mathrm{mg} / \mathrm{l} \mathrm{BAP}+0.2 \mathrm{mg} / \mathrm{lNAA}+0.2 \mathrm{mg} / \mathrm{l}$ nicotinic acid. Regenerated shoots of both species were rooted well on MS containing NAA at low concentration.
\end{abstract}

Conclusion: Hormonal differences and simple rapid in vitro regeneration protocol of $L$. cylindrica and $L$. acutangula have been established.

Keywords: Growth regulators, in vitro regeneration, ridge gourd, sponge gourd.

\section{Introduction}

Luffa cylindrica $(\mathrm{L})$ commonly known as sponge gourd is derived from the cucumber and marrow family raceme and one female flower exists in them. Its fruit, a gourd, is originated from America (Mazali and Alves 2005 ) and originated in India, where wild types still occur, but has now spread pan tropically to all areas with a high rainfall. Sponge gourd and ridge gourd, Luffa acutangula, both are diploid species with 26 chromosomes. L. cylindrica is cultivated a cross- pollinated crop (Bal et al. 2004). Sponge gourd fibers are composed of $60 \%$ cellulose, $30 \%$ hemi-cellulose (Mazali and Alves 2005). Edible portion of ridge gourd (fruit) contain $94.2 \%$ water, $1.7 \%$ fiber and leaves contain different types of vitamins and minerals.

Both plants are propagated mainly by seed, but it cannot easily maintain the genetic stability by seed propagation. On the other hand there are no conventional vegetative techniques. So, to maintain the genetic stability, it needs to develop the plants by special vegetative technique like tissue culture. A good micropropagation protocol can reduce the cost of hybrid seed production which can account for $30 \%$ of the total seedling cost. Though sponge gourd and ridge gourd have come from same genus but they show hormonal differences in different cases of tissue culture. Our present investigation describes the hormonal difference between two species using shoot tip explants for development of the rapid, simple and efficient in vitro regeneration protocols.

\footnotetext{
* Corresponding author E-mail:bsikdar2004@yahoo.com
} 


\section{Materials and Methods}

Shoot tips were collected from in vivo grown plants. The explants were cut into pieces carefully, kept in a conical flask and thoroughly washed under running tap water for $20 \mathrm{~min}$. to remove loose contaminates. They were then treated with $1 \%$ savlon for $5 \mathrm{~min}$. and washed five times with sterile distilled water under aseptic condition. For finally surface sterilization, explants were taken in laminar airflow bench and treated with $0.05 \%$ aqueous $\mathrm{HgCl}_{2}$ solution for $2.5 \mathrm{~min}$. The explants were further trimmed to remove excess tissues. Then they were cultured on MS fortified with different concentrations and combinations of BAP $(0.5-4 \mathrm{mg} /)$, KIN $(0.1-0.3 \mathrm{mg} / \mathrm{l})$, NAA (0.1$1.5 \mathrm{mg} / \mathrm{l})$, IBA (0.1- $0.8 \mathrm{mg} / \mathrm{l}), 2,4-\mathrm{D}(0.1-1.5 \mathrm{mg} / \mathrm{l}), \mathrm{GA}_{3}(0.1-0.3 \mathrm{mg} / \mathrm{l})$, nicotinic acid $(0.2 \mathrm{mg} / \mathrm{l})$ along with $3 \%$ sucrose and $0.7 \%$ agar. The $\mathrm{pH}$ of the medium was adjusted to 5.7 using $0.1 \mathrm{~N} \mathrm{NaOH}$ or $0.1 \mathrm{~N} \mathrm{HCl}$ before autoclaving and adding agar. About $10 \mathrm{ml}$ of the medium were taken in each test tube and covered with nonabsorbent cotton plug prior to autoclaving at $121^{\circ} \mathrm{C}$ for $21 \mathrm{~min}$. at $1.5 \mathrm{~kg} / \mathrm{cm}^{2}$ pressure. Cultures were incubated at $25 \pm 2^{\circ} \mathrm{C}$ under the warm fluorescent light intensity varied from $2000-3000$ lux.

\section{Results}

Among different combinations of growth regulators it was observed that shoot tip explants of sponge gourd gave significant result when MS fortified with $1.5 \mathrm{mg} / \mathrm{BAP}$ and $90 \%$ explants produced shoots and the mean number of shoot was $4.8 \pm 0.28$ (Fig. A ). But in case of ridge gourd, MS fortified with $2.0 \mathrm{mg} / \mathrm{l} \mathrm{BAP}+$ $0.2 \mathrm{mg} / \mathrm{G} \mathrm{A}_{3}$ was the best combination for shoot multiplication, where $90 \%$ explants produced shoots (Fig. E). It was observed that MS containing only BAP was better than the combinations of other hormones in sponge gourd but in ridge gourd BAP singly did not show any significant result (Table 1).

For callus induction different concentrations and combinations of different growth regulators were used. In sponge gourd when $3 \mathrm{mg} / \mathrm{l} \mathrm{BAP}+0.2 \mathrm{mg} / \mathrm{l}$ NAA was used, high degree of callus was formed (Fig. B) but in ridge gourd the best combination was $4.0 \mathrm{mg} / \mathrm{l} \mathrm{BAP}+0.2 \mathrm{mg} / \mathrm{l} \mathrm{NAA}$ (Fig. F) (Table 2). These two combinations gave light green organogenic calli which were very important for indirect regeneration, where the concentration of cytokinin was higher than auxin.

Indirect shoot regeneration from organogenic callus was observed when different concentrations and combinations of different growth regulators were used (Table 3). Sponge gourd callus produced $100 \%$ shoots when $1.5 \mathrm{mg} / \mathrm{l} \mathrm{BAP}+0.2 \mathrm{mg} / \mathrm{l} \mathrm{GA} 3$ was used and mean number of shoots per culture was $3.8 \pm 0.28$ (Fig C). In ridge gourd $100 \%$ callus produced shoots when nicotinic acid $(0.2 \mathrm{mg} / \mathrm{l})$ additionally used with BAP $(1.5$ $\mathrm{mg} / \mathrm{l})+\mathrm{NAA}(0.2 \mathrm{mg} / \mathrm{l})($ Fig. G). Efficient rooting was achieved in sponge gourd on MS medium supplemented with $0.6 \mathrm{mg} / \mathrm{l}$ NAA and $100 \%$ microshoots produced root (Fig. D) but in ridge gourd the highest result was 90\% when $0.7 \mathrm{mg} / \mathrm{l}$ NAA was used (Fig. H) (Table 4). In both cases, IBA did not show any significant result. After 21 days, well developed roots were observed and placed in pots containing sterilized humus soil $80 \%$ of which were survived.

\section{Discussion}

MS containing only BAP was better than the combinations of other hormones in sponge gourd but in ridge gourd BAP singly did not show any significant result. Haque et al. (2008) also reported similar results regarding pumpkin and ash gourd. The fortification of cytokinin for multiple shoot induction at lower concentration has been reported by Kathal et al. (1988) and Singh et al. (1996). Other species like Cucumis sativus, shoot proliferation medium was $2 \mathrm{mg} / \mathrm{BAP}+1.0 \mathrm{mg} / \mathrm{AgNO}$ ( $\mathrm{Li}$ et al. 2008). In pointed gourd the highest percentage of shoot regeneration was 93.86 when nodal explants were cultured on $\mathrm{MS}+2.0 \mathrm{mg} / \mathrm{BAP}+0.3 \mathrm{mg} / \mathrm{l} \mathrm{NAA}$ and female genotype is better than the male genotype (Malek et al. 2007). Huda and Sikdar (2006) reported that MS fortified with combination of $\mathrm{BA}, \mathrm{IBA}$ and $\mathrm{GA}_{3}$ was very good for shoot initiation and elongation from apical meristem of Bitter gourd (Mormodica charantia L.). In Zehneria scabra (L.f.) for shoot multiplication, high concentration of BAP and IAA was used by Anand and Jeyachandran (2004). 
Table 1. Effects of different concentrations and combinations of growth regulators on multiple shoot formation from shoot tips of Luffa cylindrica and Luffa acutangula

\begin{tabular}{|c|c|c|c|c|}
\hline \multirow[b]{2}{*}{ Growth regulators (mg/l) } & \multicolumn{2}{|c|}{ L. cylindrica } & \multicolumn{2}{|c|}{ L.acutangula } \\
\hline & $\begin{array}{l}\text { No of explants producing } \\
\text { shoots (out of 10) }\end{array}$ & $\begin{array}{c}\text { Mean no of } \\
\text { shoots / culture }\end{array}$ & $\begin{array}{c}\text { No of explants } \\
\text { producing shoots } \\
\text { (out of 10) }\end{array}$ & $\begin{array}{l}\text { Mena no of shoots } \\
\text { /culture }\end{array}$ \\
\hline \multicolumn{5}{|l|}{ BAP } \\
\hline 0.5 & - & - & - & - \\
\hline 1.0 & 3 & $2.3 \pm 0.07$ & - & - \\
\hline 1.5 & 9 & $4.8 \pm 0.282$ & 3 & $2.6 \pm 0.141$ \\
\hline 2.0 & 5 & $2.4 \pm 0.01$ & 5 & $2.4 \pm 0.02$ \\
\hline \multicolumn{5}{|l|}{ BAP+NAA } \\
\hline $1.5+0.1$ & 4 & $4.25 \pm 0.12$ & 5 & $1.4 \pm 0.0$ \\
\hline $2.0+0.2$ & 2 & $3.0 \pm 0.02$ & 8 & $2.1 \pm 0.08$ \\
\hline $3.0+0.2$ & - & - & 2 & $3.0 \pm 0.07$ \\
\hline $4.0+0.1$ & - & - & - & - \\
\hline \multicolumn{5}{|l|}{$\mathrm{BAP}+\mathrm{KIN}+\mathrm{GA}_{3}$} \\
\hline $1.5+0.3+0.1$ & 4 & $4.5 \pm 0.0$ & 4 & $2.75 \pm 0.05$ \\
\hline $2.0+0.3+0.3$ & 2 & $2.3 \pm 0.2$ & 1 & $2.0 \pm 0.07$ \\
\hline $2.0+0.1+0.2$ & 2 & $2.4 \pm 0.17$ & - & - \\
\hline \multicolumn{5}{|l|}{$\mathrm{BAP}+\mathrm{GA}_{3}$} \\
\hline $1.5+0.2$ & 2 & $2.4 \pm 0.01$ & 4 & $2.3 \pm 0.08$ \\
\hline $2.0+0.2$ & 2 & $1.4 \pm 0.06$ & 9 & $4.6 \pm 0.22$ \\
\hline $2.0+0.3$ & - & - & 7 & $4.1 \pm 0.01$ \\
\hline $3.0+0.3$ & - & - & 2 & $1.5 \pm 0.01$ \\
\hline
\end{tabular}

Table 2. Effects of basal media and phytohormones on induction of callus and characteristics of callus derived from shoot tips of Luffa cylindrica and Luffa acutangula after 3-4 weeks of culture

\begin{tabular}{|c|c|c|c|c|c|c|}
\hline \multirow{2}{*}{$\begin{array}{c}\text { Growth } \\
\text { regulators } \\
(\mathrm{mg} / \mathrm{l})\end{array}$} & \multicolumn{3}{|c|}{ L. cylindrica } & \multicolumn{3}{|c|}{ L. acutangula } \\
\hline & $\begin{array}{c}\text { Callus } \\
\text { induction }\end{array}$ & Callus color & $\begin{array}{l}\text { Callus } \\
\text { texture }\end{array}$ & $\begin{array}{c}\text { Callus } \\
\text { induction }\end{array}$ & $\begin{array}{l}\text { Callus } \\
\text { color }\end{array}$ & $\begin{array}{l}\text { Callus } \\
\text { texture }\end{array}$ \\
\hline \multicolumn{7}{|l|}{ BAP } \\
\hline 1.0 & - & - & - & - & - & - \\
\hline 1.5 & + & G & $C$ & - & - & - \\
\hline \multicolumn{7}{|l|}{$\mathrm{BAP}+\mathrm{NAA}-$} \\
\hline $1.5+0.1$ & + & LG & C & + & G & C \\
\hline $2.0+0.2$ & ++ & LG & C & + & G & $C$ \\
\hline $3.0+0.2$ & +++ & LG & $\mathrm{Cl}$ & ++ & LG & $C$ \\
\hline $4+0.1$ & ++ & LG & $\mathrm{Cl}$ & ++ & LG & $\mathrm{Cl}$ \\
\hline $4+0.2$ & ++ & LG & $\mathrm{C}$ & +++ & LG & $\mathrm{Cl}$ \\
\hline \multicolumn{7}{|l|}{$\mathrm{BAP}+2,4-\mathrm{D}$} \\
\hline $1.5+0.1$ & + & LG & $\mathrm{Cl}$ & + & B & $\mathrm{Cl}$ \\
\hline $2.0+0.5$ & ++ & B & $\mathrm{Cl}$ & ++ & B & $\mathrm{Cl}$ \\
\hline $2.0+1.0$ & ++ & B & $\mathrm{Cl}$ & ++ & B & $\mathrm{Cl}$ \\
\hline $3.0+1.5$ & ++ & $B$ & $\mathrm{~F}$ & + & $\mathrm{B}$ & $\mathrm{Cl}$ \\
\hline \multicolumn{7}{|l|}{ NAA } \\
\hline 0.5 & ++ & LG & $\mathrm{Cl}$ & ++ & LG & $\mathrm{Cl}$ \\
\hline 1.0 & ++ & B & $\mathrm{Cl}$ & + & B & $\mathrm{Cl}$ \\
\hline 1.5 & + & $\mathrm{B}$ & $\mathrm{Cl}$ & + & LB & $\mathrm{Cl}$ \\
\hline
\end{tabular}

G- green, LG- Light green, B- Blue 
Table 3. Effects of different concentrations and combinations of growth regulators on multiple shoots regeneration via callus of $L$ uffa cylindrical and Luffa acutangula

\begin{tabular}{ccccccc}
\hline \multirow{2}{*}{$\begin{array}{c}\text { Growth } \\
\text { regulators }\end{array}$} & $\begin{array}{c}\text { No of } \\
\text { callus } \\
\text { culture }\end{array}$ & $\begin{array}{c}\text { No of callus } \\
\text { response }\end{array}$ & $\begin{array}{c}\text { No of shoots/ } \\
\text { culture }\end{array}$ & $\begin{array}{c}\text { No of callus } \\
\text { culture }\end{array}$ & $\begin{array}{c}\text { No of callus } \\
\text { response }\end{array}$ & $\begin{array}{c}\text { No of shoots/ } \\
\text { culture }\end{array}$ \\
\hline BAP & & & & & & \\
1.0 & 10 & - & - & - & - & - \\
1.5 & 10 & - & - & 10 & - & - \\
2.0 & 10 & 2 & $1 \pm 0.0$ & 10 & - & - \\
\hline BAP + NAA & & & & & & \\
$1.0+0.1$ & 10 & 1 & $2 \pm 0.0$ & 10 & 2 & $2.5 \pm 0.0$ \\
$1.5+2.0$ & 10 & 2 & $2 \pm 0.0$ & 10 & 2 & $2.3 \pm 0.01$ \\
$2.0+0.3$ & 10 & 4 & $3.5 \pm 0.20$ & 10 & 3 & $3.0 \pm 0.2$ \\
\hline BAP +GA & & & & & & \\
$1.5+0.2$ & 10 & 10 & $3.8 \pm 0.28$ & 10 & 9 & $4.4 \pm 0.02$ \\
$2+0.3$ & 10 & 4 & $3.7 \pm 0.2$ & 10 & 7 & $3.2 \pm 0.06$ \\
\hline BAP + NAA + Nicotinic acid & 10 & 2 & $2.1 \pm 0.23$ & 10 & 10 & $4.9 \pm 0.02$ \\
$1.5+0.2+0.2$ & 10 & 1 & $2.3 \pm 0.21$ & 10 & 6 & $3.4 \pm 0.03$ \\
$2.0+0.2+0.1$ & 10 & 2 & $2.0 \pm 0.20$ & 10 & 4 & $2.5 \pm 0.2$ \\
$2.0+0.1+.01$ & 10 & & & & & \\
\hline
\end{tabular}

Table 4. Effects of auxin in semisolid MS media on root formation in in vitro regenerated shoots of $L$. cylindrica and $L$. acutangula

\begin{tabular}{|c|c|c|c|c|c|}
\hline \multicolumn{2}{|c|}{ Growth regulators } & \multicolumn{2}{|c|}{ L. cylindrical } & \multicolumn{2}{|c|}{ L. acutangula } \\
\hline Auxin & Amount (mg/l) & $\%$ of response & Root formation & $\%$ of response & Root formation \\
\hline \multirow{6}{*}{ IBA } & 0.1 & - & - & - & - \\
\hline & 0.2 & - & - & - & - \\
\hline & 0.4 & 30 & + & 20 & + \\
\hline & 0.5 & 30 & + & 30 & + \\
\hline & 0.7 & 50 & ++ & 60 & ++ \\
\hline & 0.8 & 60 & + & 50 & + \\
\hline \multirow{7}{*}{ NAA } & 0.1 & - & - & 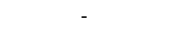 & - \\
\hline & 0.2 & 20 & + & 10 & + \\
\hline & 0.4 & 20 & + & 20 & + \\
\hline & 0.5 & 60 & ++ & 50 & + \\
\hline & 0.6 & 100 & +++ & 70 & ++ \\
\hline & 0.7 & 70 & ++ & 90 & t++ \\
\hline & 0.8 & 30 & + & 60 & ++ \\
\hline
\end{tabular}

Auxins have reported to induce callus formation in tissue culture of plant (Tissert 1995). NAA and IAA promoted excessive callus formation in water melon (Compton and Gray 1993). Halder and Gadgil (1982) was able to produce good callus from cotyledon and embryo axis in squash (Cucumiss melo) using only NAA with MS. The best development of callus was observed on medium containing $1 \mathrm{mg} / \mathrm{l} \mathrm{NAA}$ for Cucumis metuliferus (Beharav and Cohen 1994). In summer squash the highest frequency of callus induction was observed using only 2, 4-D (2.5 mg/l) with MS and hypocotyls were more responsible than epicotyls (Pal et al. 2007). Different species of cucurbitaceous have differences in callus induction. The differences occur due to many other factors like genotypes, medium composition, physical growth factors like-light, temperature, moisture which are important for callus induction (Pierik 1975).

Lou and Kako (1994) were able to produce somatic embryo and plant regeneration of cucumber. They suggested that cotyledon and first leaf derived calluses produced more embryo than callus from internodes. 
Somaclonal variation was often found when plant regenerate from callus. The increase in genetic variation that lead to the improvement was due to the phenomenon of somaclonal variation that is frequently associated with tissue culture (Larkin and Scowcroft 1981). Kathal et al. (1994) achieved good result for root induction using only IBA in C. melo. Sultana and Bari (2003) reported efficient rooting medium using low concentration $(0.1 \mathrm{mg} / \mathrm{l})$ of NAA with $1 / 2 \mathrm{MS}$ in watermelon. Anand and Jeyachandran (2004) reported that shoot elongation was simultaneously observed along with root induction using NAA in Zehneria scabra (L.f.).

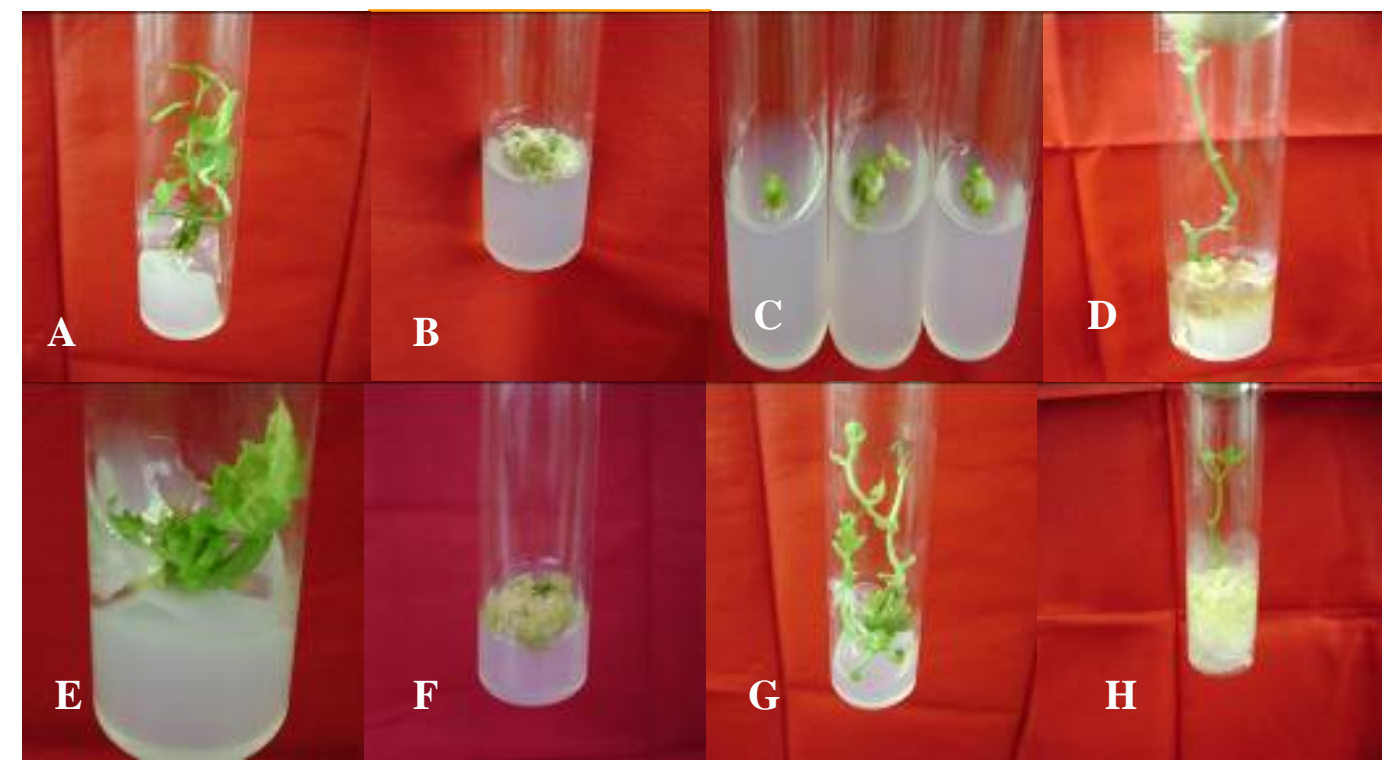

Fig.1. In vitro regeneration of Luffa cylindrica. A. direct shoots multiplication using $1.5 \mathrm{mg} / \mathrm{BAP}$. B. light green callus formation using $3.0 \mathrm{mg} / \mathrm{l}$ $\mathrm{BAP}+0.2 \mathrm{mg} / \mathrm{l} \mathrm{NAA}$. $\mathrm{C}$. indirect shoots regeneration using $1.5 \mathrm{mg} / \mathrm{l} \mathrm{BAP}+0.2 \mathrm{mg} / \mathrm{l} \mathrm{GA}$. D. root induction using $0.6 \mathrm{mg} / \mathrm{l} \mathrm{NAA}$. direct shoot multiplication using $2.0 \mathrm{mg} / \mathrm{BAP}+0.2 \mathrm{mg} / \mathrm{l} \mathrm{GA}$. F. light green callus formation using $4.0 \mathrm{mg} / \mathrm{l}$ BAP + $0.2 \mathrm{mg} / \mathrm{l} \mathrm{NAA}$. G. indirect shoot regeneration using $1.5 \mathrm{mg} / \mathrm{lBAP}+0.2 \mathrm{mg} / \mathrm{NAA}+0.2 \mathrm{mg} / \mathrm{l}$ Nicotinic acid. $\mathrm{H}$. root induction using $0.7 \mathrm{mg} / \mathrm{NAA}$

\section{Conclusions}

Hormonal differences and simple rapid in vitro regeneration protocol of $L$. cylindrica and $L$. acutangula have been established which will help in conservation and propagation of these two important species.

\section{Acknowledgements}

The authors are gratefully acknowledged USDA, MoE and MoSICT, Government of the People's Republic of Bangladesh for their financial supports.

\section{References}

Anand SP, Jeyachandran R. 2004. In vitro multiple shoot regeneration from nodal explants of Zehneria scabra (L.f.) Sonder -an important medicinal climber. Plant Tissue Cult 14(2), 101-106.

Bal KJ, Hari BKC, Radha KT, Madhusudan G, Bhuwon RS, Madhusudan PU. 2004. Descriptors for Sponge Gourd [Luffa cylindrica (L.) Roem.] NARC, LIBIRD \& IPGRI.

Beharav A, Cohen Y. 1994. Callus formation from cotyledon and hypocotyl of Cucumis melo L. and Cucumis metuliferus. Cucurbit Genetics Co operative Rep 17, 88-89.

Compton ME, Gray DJ. 1993. Shoot organogenesis and plant regeneration from cotyledon of diploid, triploid and tetraploid water melon. J Am Soc Hort Sci 118, 151-157. 
Debeaujon I, Branchard M. 1992. Induction of somatic embryogenesis and calogenesis from cotyledon and leaf protoplast-derived colonies of melon (Cucumis melo L.). Plant Cell Rep 12, 37-40. http://dx.doi:10.1007/BF00232420

Halder T, Gadgil VN. 1982. Morphogenesis in some species of the family cucurbitaceae. In: Rao AN (ed.). Tissue Culture of Economically Important Plants. Singapore National University pp. 98-103.

Haque ME, Sarkar MAR, Mahmud MA, Rezwana D, Sikdar B. 2008. In vitro propagation of Pumpkin and Ash gourd through nodal segments. J bio-sci 16, 67-71.

Huda AKMN, Sikdar B. 2006. In vitro plant production through apical meristem culture of Bitter gourd (Momordica charantia L.). Plant Tissue Cult Biotech 16(1), 31-36.

Kathal RSP, Bhatnagr, Bhojwani SS. 1988. Regeneration of plants from leaf explant of Cucumiss melo cv.pusa sharbati. Plant Cell Rep 7, 449-451. http://dx.doi:10.1016/0168-9452(94)90230-5

Kathal SP, Bhatnagar, Bhojwani SS. 1994. Plant regeneration from the callus derived root from explants of Cucumis melo L. cv. pusa sharbati Rekha. Plant sci 96, 137-142.

Larkin PJ, Scowcroft WR. 1981. Somaclonal variation -a novel source of variability from cell cultures for plant improvement. Theor Appl Genet 60, 197-214. http://dx.doi:10.1007/BF02342540

Li JX, Li JW, Ge GM. 2008. In vitro culture and plant regeneration from cotyledon of Cucumis sativus L. J Chnag Tiang Veg 1, 44-46.

Lou H, Kako S. 1994. Somatic embryogenesis and plant regeneration of Cucumber. Hort Sci 29(8), 906-909.

Malek MA, Bari Miah MA, Al-Amin M, Khanam D, Khatun M. 2007. In vitro regeneration in pointed goured. Bangladesh J Agri Res 32(3), 461-471.

Mazali IO, Alves OL. 2005. Morphosynthesis: high fidelity inorganic replica of the fibrous network of Loofa sponge (Luffa cylindrica). Acad Bras Ciên 77(1), 25-31.

Mishra AK, Bhatanagar SP. 1995. Direct shoot regeneration from the leaf explants of Cucumber (Cucumis sativus). Phytomorphology 45, 47-55.

Moreno V, Garcia, Sogo M, Granell I, Garcia-Sogo B, Roig LA. 1985. Plant regeneration from calli of Melon (Cucumis melo L. cV. "Amarillo Oro"). Plant Cell Tiss Org Cult 5, 139-146.

Moreno V, Riog LA. 1990. Somaclonal Variations in Cucurbits. In: Bajaj YPS (ed.), Biotechnology in Agriculture and Forestry, Vol II. Somaclonal variation in crop improvement I. Springer-Verlag, Berlin, Heidelberg, Germany. pp. 435-464.

Novak J, Dolezalova M. 1982. Hormone control of growth and differentiation in the in vitro cultured tissue of Cucumber (Cucumis sativus L.). Biologia (Bratislava) 37, 283-289.

Pal SP, Iftekar A, Anisuzzaman M, Kanak Kanti S, Akthar SS, Alam MF. 2007. Indirect organogenesis in summer squash (C. pepo L). Turk J Agric 31, 66-70.

Pierik RLM. 1975. Plantent it in kweek buizen. Thieme, Zutphen, the Netherland. pp. 1-164.

Singh MN, Mishra AK, Bhatnagar SP. 1996. In vitro production of plants from colyledon explant of Cucumis melo L. and their successful transfer to field. Phytomorphology 46, 395-402.

Sultana RS, Bari MA. 2003. Effect of different plant growth regulators on direct regeneration of water melon (Citrullus lanatus Thumb.). Plant Tiss Cult 13, 173-177.

Tissert B. 1995. Embryogenesis, organogenesis and plant regeneration. In: Dixon RA (ed). Plant Cell Culture: A Practical Approach, IRL Press Oxford, Washington, DC. 